\title{
NECESSITY AND DEATH: LESSONS FROM LATIMER AND The Case of The Conjoined Twins
}

\author{
GARY T. TROTTER
}

The availability of the defence of necessity in cases of homicide is a complex issue in both Canadian and British jurisprudence. This article examines the divergent judicial and academic views and argues that, while necessity may be available for certain kinds of homicide. it should be rejected as a legitimate defence to intentional killings. The author looks closely at wo recent cases in which the question arose as to whether or not killing a human being is ever justifiable or excusable on the basis of necessity: the Canadian case of R. $v$. Latimer and the British case of Re A (Children).

The author argues that the approach of the Latimer court is preferable, advancing this position from a number of angles. Underlying rationales for the defence of necessity in Anglo-Canadian jurisprudence are examined, as well as the conceptually similar defence of duress, both at common law and in s. 17 of the Criminal Code. Both of these points are reinforced and analyzed via a discusion of the sanctity-of-life principle in Canadian criminal law. The article makes clear the essential nature of the issues raised in both Latimer and $\operatorname{Re} A$ (Children), as they engage fundamental questions of value for our society.
La disponibilité de l'excuse de nécessité dans les affaires d'homicide est une question complexe dans le droit canadien et britannique. Cet article examine les opinions judiciaires et acadèmiques divergentes et fait valoir le fait que. bien que la nécessité existe pour certains genres d'homicides. elle devrait être rejetée en tant que défense légitime pour les homicides intentionnels. L'auteur examine deux affaires récentes pour lesquelles la question a été soulevée, à savoir si l'homicide d'une personne peut ètre justifiée ou excusable sur la base de la nécessité. Il s'agit de l'affaire canadienne de R. c. Latimer et l'affaire britannique de $\operatorname{Re} A$ (Children). $L$ 'auteur fait valoir que la démarche de la cour dans l'affaire Latimer est préférable, invoquant celte position à partir d'un certain nombre de points de vue. Les raisonnements sous-jacents pour l'excuse de nécessité dans le droit anglo-canadien y sont étudiés tout comme la défense semblable au point de vue conceptuel de contrainte. autant dans la common law quä l'article 17 du Code criminel. Ces deux points sont renforcés et analysés au moyen d'une discussion sur le caracière sacré de la vie dans le droit criminel canadien. Cet article jette la lumière sur la nature essentielle des questions soulevées dans les causes Latimer et $\operatorname{Re} \mathrm{A}$ (Children), étant donné qu'elles touchent des questions de valeur fondamentales pour notre société.

\section{TABLE OF CONTENTS}

I. INTRODUCTION $\ldots \ldots \ldots \ldots \ldots \ldots \ldots \ldots \ldots \ldots \ldots \ldots \ldots$

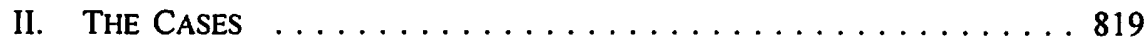

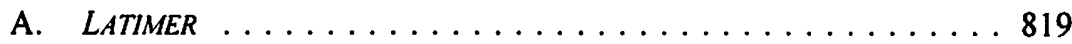

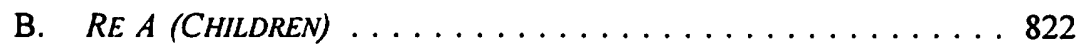

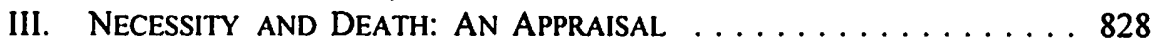

A. THE Foundations OF NECESSITY: THE EXCUSEJUSTIFICATION TENSION . . . . . . . . . . . . . . 829

B. THE SANCTITY OF LIFE, INNOCENT VICTIMS

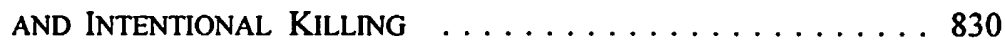

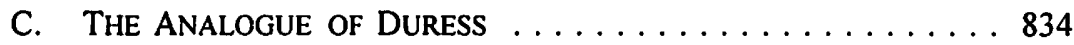

IV. NeCESSity AND DEATH — THE FUtURE $\ldots \ldots \ldots \ldots \ldots \ldots 839$

Faculty of Law, Queen's University. I wish to thank Tammy D'Eri (Queen's Law, 2002) for her excellent research assistance. I would also like to thank my colleague Don Stuart for his comments on an earlier draft of this article. 


\section{INTRODUCTION}

This article considers whether killing a human being is ever justifiable or excusable on the basis of necessity. For over 100 years, the English case of $R$. v. Dudley and Stephens ${ }^{\prime}$ has been authoritative. The facts of this case are well known. The accused sailors, adrift on a lifeboat for many days, murdered and ate a weak cabin boy who was soon to expire. When Dudley and Stephens were rescued, they were charged with murder and pleaded necessity in their defence. This claim was rejected by Lord Coleridge C.J. in the following terms:

But the temptation to the act which existed here was not what the law has ever called necessity. Nor is this to be regretted. Though law and morality are not the same, and many things may be immoral which are not necessarily illegal, yet the absolute divorce of law from morality would be of fatal consequence; and such divorce would follow if the temptation to murder in this case were to be held by law an absolute defence of it. It is not so. To preserve one's life is generally speaking a duty, but it may be the plainest and the highest duty to sacrifice it... It is not correct, therefore, to say that there is any absolute or unqualified necessity to preserve one's life... Who is to be the judge of this sort of necessity? By what measure is the comparative value of lives to be measured? Is it to be strength, or intellect, or what? It is plain that the principle leaves to him who is to profit by it to determine the necessity which will justify him in deliberately taking another's life to save his own. ${ }^{2}$

The Court declared that the actions of the accused constituted willful murder admitting of no excuse known to law.

The words of Lord Coleridge have stood the test of time. However, the soundness of his views has been tested in two recent cases where necessity was pleaded in an attempt to justify killing. In Canada, the issue proved to be a strong, though unresolved, undercurrent in the Supreme Court's decision in R. v. Latimer. ${ }^{3}$ In England, the issue was crucial to the decision of the Court of Appeal in the unusual and sad case of $R e$ $A$ (Children) (Conjoined Twins: Surgical Separation). ${ }^{4}$ In Re A (Children), the Court of Appeal, Civil Division concluded that necessity could justify the intentional taking of a life. In Latimer, while it was not necessary for the Supreme Court to confront the issue directly, the Court suggested in very strong terms that the weight of authority did not support the application of the defence of necessity to homicide. Released within months of each other, ${ }^{5}$ these two decisions provide an opportunity to consider the relationship between necessity and death.

This divergence in views signals the complexity of the issue. This article argues that, while necessity may be available for certain forms of homicide, it should not be recognized as a defence to intentional killings. Thus, the approach of the Court in Latimer is preferable to $\operatorname{Re} A$ (Children). This position is developed from a number of

(1884), 14 Q.B.D. 273 [hereinafter Dudley and Stephens].

Ibid. at 287.

(2001), 150 C.C.C. (3d) 129 (S.C.C.) [hereinafter Latimer].

[2000] 4 All E.R. 961 (C.A.) [hereinafter $\operatorname{Re} A$ (Children)].

Re A (Children) was decided on 22 September 2000; Latimer was decided on 18 January 2001. 
perspectives. First, the exclusion of intentional killings from the ambit of the necessity defence is supported by underlying rationales for the defence in Anglo-Canadian jurisprudence, which is a blend of excusing and justificatory preconditions. The Supreme Court has held in Latimer, and in its predecessor, $R$. v. Perka, ${ }^{6}$ that the defence is conceptualized as an excuse. However, its availability is preconditioned by considerations of proportionality, which require that the harm inflicted not be disproportionate to the harm avoided. ${ }^{\text {? }}$

Secondly, in arguing that an intentional killing is never proportionate for the purposes of necessity, reliance is placed on the conceptually similar defence of duress, both at common law and in s. 17 of the Criminal Code. ${ }^{8}$ Section 17 excludes murder, attempted murder and other forms of intentional harm from the scope of the defence. The common law defence of duress replicates this theme at the high end in that the British courts have come to the position that duress is inapplicable to murder and attempted murder. The approach to necessity and death ought to be developed in a similar manner. Lastly, and really underlying both of the previous arguments, the exclusion of intentional killings from the ambit of the necessity defence is supported by the sanctity-of-life principle in Canadian criminal law.

\section{THE CASES}

\section{A. LATIMER}

The facts in Latimer are so notorious that they do not require elaborate discussion. ${ }^{9}$ Latimer killed his severely disabled daughter, Tracy, to stop the unspeakable pain she suffered from severe cerebral palsy. Horrified at the prospect of Tracy enduring another serious operation, Latimer decided to relieve her of the pain. He placed her in the cab of his truck, ran a hose from the exhaust pipe, and killed her with carbon monoxide.

Latimer was charged with first-degree murder. After his first trial, he was convicted of second-degree murder. ${ }^{10}$ The Saskatchewan Court of Appeal upheld his

9 See the extensive discussion of this case in the symposium on the case, now published in (2001)

64 Sask. L. Rev., entitled "Perspectives on the Latimer Trial."

(1984), 42 C.R. (3d) 113 (S.C.C.) [hereinafter Perka].

Latimer, supra note 3 at 144 , Perka, ibid. at 133 . This is like some forms of self-defence, such as that codified in s. 37 of the Criminal Code, which requires that an individual fending off an assault use no more force than is necessary to prevent the assault or repetition of it. Self-defence is the archetypal justificatory defence.

R.S.C. 1985 , c. C-46 [hereinafter Criminal Code]. See R. v. Hibbert (1995), 99 C.C.C. (3d) 193 (S.C.C.) and R. v. Ruzic (2001), 153 C.C.C. (3d) I (S.C.C.). In Hibbert, Lamer C.J.C. held, at 222. that "It would, I believe, be highly anomalous if the common law defence of duress were to be understood as based on substantially different juridical principles from the common law defence of necessity."

It is somewhat of a mystery how the jury arrived at its verdict on second-degree murder. On the evidence, first-degree murder seemed like the only realistic option for the jury. As Professor Kent Roach surmises, the verdict may have been the result of jury nullification, the jury being concerned that a conviction for first-degree murder in the circumstances was too harsh: see K. Roach. "Crime and Punishment in the Latimer Case" (2001) 64 Sask. L. Rev. 469. 
conviction. ${ }^{11}$ The Court split on whether the minimum mandatory sentence for seconddegree murder (life imprisonment with 10 years parole ineligibility) was constitutional. Chief Justice Bayda held that, in the circumstances, the sentence was cruel and unusual. On further appeal, the Supreme Court of Canada held that a new trial was warranted because there was evidence that the prosecutor had interfered with the jury selection process. $^{12}$

Latimer was again convicted of second-degree murder after his second trial. The principal ground of appeal from his second conviction was that the trial judge erred in refusing to leave the defence of necessity with the jury. This argument was rejected by the Saskatchewan Court of Appeal. ${ }^{13}$ This decision was ultimately affirmed by the Supreme Court of Canada. While there are other aspects of the Court's decision worthy of note, this article focuses on that part of the judgment that bears on the question of whether necessity is ever available with respect to an intentional killing. ${ }^{14}$

In Latimer, the Supreme Court built on its earlier decision in Perka in articulating the contours of the defence of necessity. In Perka, Dickson J. (as he then was) spoke of necessity as an excuse, and not a justification, in the following way:

It rests on a realistic assessment of human weakness, recognizing that a liberal and humane criminal law cannot hold people to the strict obedience of laws in emergency situations where normal human instincts, whether of self-preservation or of altruism, overwhelmingly impel disobedience. The objectivity of the criminal law is preserved; such acts are still wrongful, but in the circumstances they are excusable. Praise is indeed not bestowed, but pardon is. ${ }^{15}$

Justice Dickson strongly disapproved of a vision of necessity that was predicated on a justificatory basis, involving a utilitarian balancing of the benefits of obeying the law as opposed to disobeying it. As Dickson J. said,

The Criminal Code has specified a number of identifiable situations in which an actor is justified in committing what would otherwise be a criminal offence. To go beyond that and hold that ostensibly illegal acts can be validated on the basis of their expediency would import an undue subjectivity into the criminal law. It would invite the courts to second-guess the legislature and to assess the relative merits of social policies underlying criminal prohibitions. Neither is a role which fits well with the judicial function. Such a doctrine could well become the last resort of scoundrels and, in the words of

$11 \quad$ (1995), 99 C.C.C. (3d) 481 (Sask. C.A.).

12 (1997), 112 C.C.C. (3d) 193 (S.C.C.).

13 (1998), 131 C.C.C. (3d) 191 (Sask. C.A.).

is For very diverse accounts about different aspects of the Court's decision and its implications, see H.A. Kaiser, "Latimer: The End of Judicial Involvement and an Unsatisfactory De Facto Beginning of the Clemency Process" (2001) 39 C.R. (5th) 42; A. Manson, "Motivation, the Supreme Court and Mandatory Sentencing for Murder" (2001) 39 C.R. (5th) 65; B. Sneiderman, " $R$ v. Latimer: Juries and Mandatory Penalties" (2001) 39 C.R. (5th) 29; and D. Stuart, "A Hard Case Makes for Too Harsh Law" (2001) 39 C.R. (5th) 58. See also the conference proceedings published in the Saskatchewan Law Review, supra note 9. 
Edmund Davies L.J. in Southwark London Borough Council v. Williams, [1971] Ch. 734 at 746 ... it could "very easily become simply a mask for anarchy". ${ }^{16}$

Justice Dickson then elaborated on his view of necessity, based on moral or normative involuntariness, accompanied by very strict limitations, including a requirement of proportionality that "that the harm inflicted must be less than the harm sought to be avoided."'7

The Latimer Court also echoed Dickson J.'s concerns that the defence be restricted to cases of true involuntariness and that the defence be "strictly controlled and scrupulously limited." 18 This approach to necessity as a strictly controlled excuse was operationalized into three elements:

(a) There is a requirement of imminent peril or danger. This requirement is determined on the basis of a modified objective test; ${ }^{19}$

(b) The accused must have had no reasonable alternative to the course of action he or she undertook. This element is also determined on the basis of a modified objective test ${ }^{20}$ and

(c) There must be proportionality between the harm inflicted and the harm avoided. This last requirement is approached from a purely objective perspective. $^{21}$

The last factor, proportionality, is the focus of this article. The Latimer Court expressed this factor in slightly more generous terms than Dickson J. envisioned in Perka:

In this regard, it should be noted that the requirement is not that one harm (the harm avoided) must always clearly outweigh the other (the harm inflicted). Rather, the two harms must, at a minimum, be of a comparable gravity. That is, the harm avoided must be either comparable to, or clearly greater than, the harm inflicted. As the Supreme Court of Victoria in Australia has put it, the harm inflicted "must not be out of proportion to the peril to be avoided": $R$. v. Loughnan, [1981] V.R. 443 at p. 448. 22

Proportionality is somewhat out of place in the conceptualization of necessity as an excuse because it speaks more to considerations of justification, rather than excuse. As the Latimer Court said, it involves an evaluation of society's values as to what is appropriate and what represents a transgression, ${ }^{23}$ and alludes to a comparison of the harm inflicted and the harm avoided. This language is perilously close to the "lesser of two evils" conceptualization of necessity, which the Court had previously rejected in

Ibid. at 129-30.

Ibid. at 133.

Latimer, supra note 3 at 143.

Ibid. at 143-44.

Ibid. at 144.

Ibid. at 144-45.

Ibid.

Ibid. at 146. 
Perka. ${ }^{24}$ More perplexing is that the Latimer Court has given proportionality preeminent status by recommending that, where it is apparent that the accused's acts are disproportionate, it is preferable for the judge to rule out necessity without considering the other parts of the necessity test. ${ }^{25}$

In its discussion of proportionality, the Court considered the question of whether a homicide can ever be defended on the basis of necessity. It was not, strictly speaking, necessary for the Court to confront this issue, as it had already determined that there was no air of reality to the first two prongs of the necessity defence. Nevertheless, the Court said,

It is difficult, at the conceptual level, to imagine a circumstance in which the proportionality requirement could be met for a homicide. We leave open, if and until it arises, the question of whether the proportionality requirement could be met in a homicide situation. In England, the defence of necessity is probably not available for homicide... The famous case of $R$. v. Dudley and Stephens ... involving cannibalism on the high seas, is often cited as establishing the unavailability of the defence of necessity for homicide, although the case is not conclusive... The Law Reform Commission of Canada has suggested the defence should not be available for a person who intentionally kills or seriously harms another person. ${ }^{26}$

The Court held that it was out of all proportion for Latimer to have killed his daughter to spare her the suffering caused by a condition that was not life-threatening. ${ }^{27}$

\section{B. RE A (CHILDREN)}

The case of $\operatorname{Re} A$ (Children) provides a highly unlikely context for the discussion of necessity. The concerned twin girls, Jodie and Mary, were born conjoined at the abdomen. Mary, the weaker of the twins, was not strong enough to pump sufficient oxygenated blood through her body. Had she been born independent, she would not have survived. Mary also had other severe neurological and cardiovascular problems. Mary did not have developed lungs and was unable to cry. Combined with her neurological problems, it was impossible to tell when she experienced pain. However, Mary shared a common artery with Jodie that permitted Mary to receive life-sustaining oxygenated blood. If Mary were to be separated from her sister, she would die almost immediately. However, when the matter came before the courts, both girls would have died within three to six months without any surgical intervention, due to the stress on Jodie of circulating blood for the two of them. ${ }^{28}$ Complicating the situation was the fact that, if the operation to separate the twins was a "planned elective" separation, the

\section{Supra note 6.}

Latimer, supra note 3 at 144 .

Ibid. at 148 [citations omitted]. The Court noted the divided American academic authority on the issue. The Court's comment that it is "difficult, at the conceptual level," to imagine the defence of necessity applying to homicide, might be an overstatement. One could at least "imagine" more favourable circumstances in which the defence might operate, perhaps when one individual might be sacrificed to save the lives of many children.

lbid. at 149.

Supra note 4 at 969. 
chances of survival of Jodie were much higher. However, if the physicians waited for an emergency situation, when Mary began to pass away, then Jodie's chances of survival decreased rapidly. ${ }^{29}$

The parents of Jodie and Mary were devout Catholics who were opposed to any medical intervention, preferring to leave the situation in God's hands. ${ }^{30}$ The physicians who cared for the girls were confident they could carry out an operation that would give Jodie a worthwhile life. The hospital sought a declaration permitting them to carry out the operation. The High Court Judge, Johnson J., made the declaration sought ${ }^{31}$ and the parents appealed.

The Court of Appeal examined the legality of the proposed procedure to evince its lawfulness from many different angles, taking into account medical, family and criminal law. Ultimately, the Court affirmed the decision of Johnson J. that the operation could be lawfully performed. This article is restricted to a discussion of the Court's analysis of the criminal implications of the surgical procedure.

In evaluating whether the actions of the physicians would constitute murder, Ward and Brooke L.JJ., in separate judgments, concluded that, all other things being equal, they would be. They concluded that, because the death of Mary was a virtually certain outcome of the surgery, the physicians would have the intent for murder even though Mary's death was not the desired result. ${ }^{32}$ Lord Justice Ward further postulated that, by not acting to save Jodie, the parents would be breaching a duty to Jodie and might be equally culpable of killing Jodie. ${ }^{33}$ It is never really clear from the judgment of Walker L.J. whether he considered the killing of Mary to be culpable. ${ }^{34}$

Having concluded that criminal liability could attach, their Lordships turned to potential defences. Because the judges reached the same conclusion by different routes, it is helpful to consider their reasons individually. Each judge confronted the obstacle faced by the House of Lords' decision in $R$. v. Howe, which decided that the defence of duress is not applicable to murder. ${ }^{35}$ Building on the authority of Dudley and Stephens, which held that the defence of necessity is not available to a charge of murder, Lord MacKay of Clashfern said, in Howe,

it seemed repugnant that the law should recognise in any individual in any circumstances, however extreme, the right to choose that one innocent person should be killed rather than another. In my

Ibid. at 1012 (per Ward L.J.) and at 1023-29 (per Brooke L.J.). All three judges relied on the House of Lords' decision in $R$ v. Woollin, [1998] 4 All E.R. 103. See A. Ashworth \& B. Mitchell, eds.. Rethinking English Homicide Law (Oxford: Oxford University Press, 2000).

Ibid. at 1013.

Ibid. 1062-67.

[1987] I All E.R. 771 [hereinafter Hove]. 
opinion that is the question which we still must face. Is it right that the law should confer this right in any circumstances, however extreme? ${ }^{36}$

All three judges in Re A (Children) sought to distinguish both Dudley and Stephens and Howe in order to conclude that the operation was lawful from a criminal law perspective.

\section{THE REASONS OF WARD L.J.}

Crucial to Ward L.J.'s decision was his recognition of a conflicting duty on the doctors - a duty to Mary to not operate because it would kill her, and a conflicting duty to Jodie to operate because failure to do so would result in her death. ${ }^{37}$ Lord Justice Ward held that this conflicting duty distinguished the case from Howe, where no such conflict existed. In coming to this conclusion, Ward L.J. found the concurring reasons of Wilson J. in Perka to be persuasive. Justice Wilson agreed with the majority's preference for considering necessity to be an excuse, but thought that some scope for the operation of necessity as a justification ought to be preserved. ${ }^{38} \mathrm{~A}$ defence of necessity based on justificatory principles may have profoundly different features than one based on excuse. For instance, necessity as a justification requires no sense of immediacy or urgency, because the action is considered to be rightful..$^{39}$ This was an appealing notion to the judges in $\operatorname{Re} A$ (Children) because the doctors did not face an emergency situation approximating moral involuntariness.

However, Wilson J. did not advocate a free-floating justification approach to necessity, in which the balancing of harms - in a broad utilitarian sense - would be performed. Justice Wilson restricted necessity as a justification to those situations where the accused is faced with the need to fulfill a legal duty that conflicts with the one which he or she is charged with having breached. ${ }^{40}$ Justice Wilson further held that the justification-based defence of necessity entails considerations of proportionality, given that the rightfulness of the accused's choice between conflicting legal duties is at stake. On the issue of proportionality and death, she said,

As the facts before the court in the present case do not involve a conflict of legal duties, it is unnecessary to discuss in detail how a court should go about assessing the relative extent of two evils. Suffice it to say that any such assessment must respect the notion of right upon which justification is based. The assessment cannot entail a mere utilitarian calculation of, for example, lives saved and deaths avoided in the aggregate, but must somehow attempt to come to grips with the nature of the rights and duties being assessed. This would seem to be consistent with Lord Coleridge's conclusion

Ibid. at 798.

Supra note 4 at 1015 .

Supra note 6. Wilson J. said, at 145 , "My concern is that the learned Chief Justice appears to be closing the door on justification as an appropriate jurisprudential basis in some cases and I am firmly of the view that this is a door which should be left open by the court."

Ibid. at 150: "The fact that one act is done out of a sense of immediacy or urgency and another after some contemplation cannot, in my view, serve to distinguish the quality of the act in terms of right or wrong."

Ibid. 
[in Dudley and Stephens] that necessity can provide no justification for the taking of a life, such an act representing the most extreme form of rights violation. As discussed above, if any defence for such a homicidal act is to succeed, it would have to be framed as an excuse grounded on self-preservation. If could not possibly be declared by the court to be rightful. ${ }^{41}$

While Ward L.J. found Wilson J.'s justification analysis useful, especially given the conflict of legal duties thrust upon the doctors by Mary and Jodie's situation, he rejected the rest of Wilson J.'s proportionality analysis that was based on the principle of universality of rights. ${ }^{42}$ Lord Justice Ward rejected this analysis because the conflicting duties both involved the issue of life and death. He held that the operation, if performed, would be lawful and the lesser of two evils. ${ }^{43}$

Lord Justice Ward offered an alternative basis for why the doctors were entitled to undertake the operation. He compared the situation to one of "quasi self-defence," arguing that Mary, by her weak condition, was killing Jodie. Recognizing that Mary was doing nothing unlawful did not preclude the doctors from intervening to stop the effect that Mary was having on Jodie. Lord Justice Ward compared the twins' situation to an example of a six-year-old boy shooting at other children in a schoolyard. Lord Justice Ward held that the police would be justified in killing the boy to protect the others even though the boy's actions were not, strictly speaking, unlawful, due to his age. However, Ward L.J. reasoned, his acts would probably not be morally innocent. Lord Justice Ward held that the situation was no different in this case, as the doctors would be "removing the threat of fatal harm to [Jodie] presented by Mary's draining of her life-blood."

\section{THE REASONS OF BROOKE L.J.}

Lord Justice Brooke provided a more compelling explanation of the criminal dimension of the issue faced by the Court. He concluded that, unless the criminal law provided some excuse or justification, the operation and its inevitable fatal consequences for Mary would constitute murder. ${ }^{45}$ Lord Justice Brooke engaged in a thorough and scholarly review of the history of the defence of necessity in the British context. On the crucial issue of whether necessity is a ever a defence to homicide,

Ibid. at 153 [emphasis added].

$\$ 2 \quad$ bid. As Wilson J. said at 147, "The underlying principle here is the universality of rights, that all individuals whose actions are subjected to legal evaluation must be considered equal in standing. Indeed, it may be said that this concept of equal assessment of every actor, regardless of his particular motives or the particular pressures operating upon his will, is so fundamental to the criminal law as rarely to receive explicit articulation." This is undoubtedly derived from the work of Immauel Kant, who said, "Right is therefore the sum of the conditions under which the choice of one can be united with the choice of another in accordance with a universal law of freedom.... Any action is right if it can coexist with everyone's freedom in accordance with a universal law." See I. Kant, Metaphysics of Morals in Practical Philosophy, M.J. Gregor, ed. and trans. (Cambridge: Cambridge University Press, 1996) at 230-31. $\operatorname{Re} A$ (Children), supra note 4 at 1015-16.

Ibid. at 1016-17. The distinction is not particularly apt. While the six-year-old boy is not legally accountable for his actions, the actions themselves are obviously unlawful.

Ibid. at 1027-29. 
Brooke L.J. held that Dudley and Stephens, as well as its duress cousin, $R$. v. Howe, were distinguishable precedents. Referring to Dudley and Stephens, Brooke L.J. explained:

That case has sometimes been taken as authority for the proposition that necessity can never under any circumstances provide a legal justification for murder. While it is true that a passage in the speech of Lord Hailsham in $R v$. Howe ... might be interpreted to this effect, in my judgment neither that passage nor a similar passage in Lord MacKay of Clashfern's speech ... displays any evidence that they had in mind a situation in which a court was invited to sanction a defence (or justification) of necessity on facts comparable to those with which we are confronted in the present case. I accept Miss Davies's submission that $R$. v. Dudley and Stephens, endorsed though it was by the House of Lords in $R v$. Howe, is not conclusive of the matter. ${ }^{46}$

Lord Justice Brooke then marshalled authority on both sides of the debate about whether the defence of necessity, if it should be recognized at all, ought to cover situations of homicide. The most notable proponent against recognizing the defence in the context of murder is Glanville Williams in his Textbook of Criminal Law, ${ }^{47}$ in which he convincingly argues that the sanctity-of-life principle prohibits the recognition of necessity in these circumstances because the victim is an innocent agent. ${ }^{48}$

Lord Justice Brooke also considered the notion of characterizing the situation of the conjoined twins as one of quasi-self-defence. Instead of relying on Ward L.J.'s example of the six-year-old boy in a schoolyard, he referred to the example of the mountaineer who is roped to a climber who has fallen and then decides to cut his doomed partner loose in order to save his own life. ${ }^{49}$ Lord Justice Brooke concluded that, while the fallen partner was not committing an unlawful act, he was infringing on the freedom of the mountaineer who was justified in saving his own life by cutting his partner loose. The fallen mountaineer example is much like the real-life Zeebrugge disaster during which an army corporal ordered that a man frozen (by cold and fear) on a rope ladder be pushed off the ladder because his immobility was seriously jeopardizing the safety of others who were in danger of drowning. The man was pushed off the ladder so that others could climb to safety. The man was never seen again and was presumed to be dead. ${ }^{50}$ Lord Justice Brooke held that these two examples presented scenarios distinguishable from Dudley and Stephens, mainly because there was no question of who would be chosen to die (a concern raised by Lord Coleridge in Dudley and Stephens). Moreover, in both scenarios, the person self-selected for death was imperiling the lives of others, albeit unintentionally. ${ }^{51}$ Lord Justice Brooke placed Mary in the same category as the fallen mountaineer and the frozen man on the ladder.

Ibid. at 1038.

G. Williams, Textbook of Criminal Law, 2d ed. (London: Stevens \& Sons, 1983) at 603-604. Williams, ibid. at 603, distinguishes death and necessity from death and self-defence because, with the latter, the defence operates only against aggressors, who are, with rare exceptions, wrongdoers. This example is given by Williams, ibid. at 604. See also J.C. Smith, Justification and Excuse in the Criminal Law (London: Stevens \& Sons, 1989) at 73; and J. Horder, "Self-Defence, Necessity and Duress: Understanding the Relationship" (1998) 1/ Can. J.L. \& Juris. 143.

Supra note 4 at 1041 .

Ibid. 
Like Ward L.J., Brooke L.J. preferred the approach of Wilson J. in Perka in which she left open the possibility of necessity as a justification when an individual is confronted with conflicting legal duties. ${ }^{52}$ However, Brooke L.J. rejected Wilson J.'s reliance on the universality of rights and the sanctity of life as barriers to the application of the defence in the context of homicide.

In the final analysis, Brooke L.J. pronounced that there were sound policy reasons for departing from Dudley and Stephens and Howe. First, the question of choosing a victim was not applicable because, by virtue of her unfortunate circumstance, Mary was already "self-designated for a very early death." concerns about divorcing law and morality, Brooke L.J. observed that Parliament permits abortions to be carried out in certain conditions. He combined this reality with the view that it might be immoral not to assist Jodie if there was a good prospect for giving her a happy and fulfilled life by carrying out the operation. As Brooke L.J. held, "All that a court can say is that it is not at all obvious that this is the sort of clear-cut case, marking an absolute divorce from law and morality, which was of such concern to Lord Coleridge and his fellow judges." 54 Further, Brooke L.J. held that the circumstances of the case did not give rise to a concern, expressed by some commentators, ${ }^{55}$ that the recognition of a defence of necessity in answer to a homicide charge would make people too ready to avail themselves of the defence. In this light, he observed that the rarity of conjoined twins cases, and the involvement of the medical establishment responsible for their care, almost always permit prior judicial authorization of these decisions. ${ }^{56}$

\section{THE REASONS OF WALKER L.J.}

Lord Justice Walker provided the shortest judgment of the Court, with little focus on the criminal law issues. His Lordship engaged in a ponderous discussion of intent, never quite making it clear whether the intent for murder would be satisfied if the operation were performed. ${ }^{57}$ On the issue of necessity, Walker L.J. found no assistance from the previous British authorities on the issue of necessity and death in deciding the fate of the conjoined twins. However, like the other members of the Court, he found the views of Wilson J. in Perka to be helpful, especially as it related to the concept of conflicting legal duties. ${ }^{58}$ Lord Justice Walker conceded that,

In truth there is no helpful analogy or parallel to the situation which the court has to consider in this case. It is unprecedented and paradoxical in that in law each twin has the right to life, but Mary's

Ibid. at 1048-50.

Ibid. at 1051 .

Ibid.

See, e.g., J. Stephen, A History of the Criminal Law of England, vol. 2 (London: MacMillan, 1883) at 107-108.

Supra note 4 at 1051-52.

See D. Stuart, Canadian Criminal Law: A Treatise, 4th ed. (Scarborough: Carswell, 2001) at 522. n. 466.

Supra note 4 at 1065-66. 
dependence on Jodie is severely detrimental to Jodie, and is expected to lead to the death of both twins within a few months. ${ }^{59}$

In the end, Walker L.J. simply concluded that the law of necessity should develop on a case-by-case basis, saying,

I would extend it, if it needs to be extended, to cover this case. It is a case of doctors owing conflicting legal (and not merely social or moral) duties. It is a case where the test of proportionality is met, since it is a matter of life and death, and on the evidence Mary is bound to die soon in any event.... It should not be regarded as a step down a slippery slope because the case of the conjoined twins presents an unique problem. ${ }^{60}$

\section{IN SEARCH OF A RATIO}

Because all three judgments are so wide-ranging, it is not entirely clear on what basis the decision turned. Lord Justice Brooke is the strongest proponent of necessity in the circumstances. Lord Justice Ward favoured some version of private defence. The decision of Walker L.J. is the most elusive, mostly because the issue of intent is not clearly resolved. In the passage reproduced just above, Walker L.J. was prepared to extend the defence of necessity to cover the case of the conjoined twins, if it was necessary to find such a justification. John $\mathrm{C}$. Smith argues that the ratio of the decision must be found in the judgments of Brooke and Ward L.JJ.:

Whether it is regarded as a case of private defence, or of necessity, the result is the same and may be summed up as follows: Where $A$ is, as the defendant knows, doomed to die in the near future but even the short continuation of his life will inevitably kill B as well, it is lawful to kill A, however free of fault he may be. ${ }^{61}$

On 7 November 2000 , the surgery was performed. Mary died almost immediately after being separated from her sister. ${ }^{62}$

\section{NECESSITY AND DEATH: AN APPRAISAL}

The contrasting views reflected in Latimer and Re A (Children) have left the question of necessity and death in a state of uncertainty as far as the law in both countries is concerned. As a matter of formal interpretation, it can still be argued, in both jurisdictions, that the defence of necessity will not be available in cases of homicide. As far as England is concerned, the modalities of reasoning of all three judges in $R e$ $A$ (Children) turned tightly on the idiosyncratic facts of the case, leaving little room for the assertion of a more general proposition that necessity is available in homicide cases.

lbid. at 1066.

Ibid. at 1067.

J.C. Smith. "Case Comment on Re A (Children)" [2001] Crim. L.R. 401 at 405.

See "One Conjoined Twin Survives Operation" (7 November 2000), online: CNN <www.cnn.com/ 2000/WORLD/europe/UK/11/07/twins.operation.02/index.html> (date accessed: 8 January 2003). See J. Rogers, "Necessity, Private Defence and the Killing of Mary" [2001] Crim. L.R. 515 at 516. n. 11 . 
In Canada, the situation is even more straightforward. The Court's obiter comments cited above ("It is difficult, at the conceptual level, to imagine a circumstance in which the proportionality requirement could be met for a homicide" ${ }^{63}$ ) is a strong assertion that the defence will not likely be available in murder cases. Of course, it is difficult to determine whether this statement was meant to cover all "homicides," or whether the Court intended to restrict its remarks to future cases of murder, the charge that Latimer faced.

Beyond parsing the words of both courts, the exclusion of homicide from the ambit of the defence of necessity is more fundamentally justified by broader legal traditions. This assertion is based on the following considerations: (a) the accepted theoretical basis of the necessity defence; (b) the pervasiveness of the sanctity-of-life principle in the criminal law; and (c) the analogue of duress in Canadian and British law.

\section{A. The Foundations of NeCESSITY: The EXCuSE-Justification Tension}

The theoretical formulation of the defence of necessity in Canada rests on several limitations that suggest that death is not contemplated in its range. The rigid preconditions for the operation of the defence, conceptualized as an excuse, first articulated in Perka and later reinforced in Latimer, confirm that its scope is meant to be narrow. The organizing principle of moral or normative involuntariness carries with it strict requirements that ensure the defence is not easily accessed. Even after conceiving of necessity as an excuse, Dickson J. limited the defence by saying that "the harm inflicted must be less than the harm sought to be avoided." ${ }^{34}$ No consideration was given to the fact that this limitation, a proportionality requirement, more appropriately fit into necessity as a justification, rather than an excuse. ${ }^{65}$

Justice Wilson's approach to necessity as a justification more obviously engages considerations of proportionality. Indeed, in the passages from Wilson J.'s judgment in Perka, cited by the Court of Appeal in Re A (Children), she stressed the importance of proportionality in the context of life and death. The Court of Appeal was content to pick and choose from the aspects of Wilson J.'s judgment that they found appealing, accepting her conceptualization of necessity as a justification, while rejecting her claims of proportionality centred on death.

Justice Wilson's thinking on necessity and death is represented in the Latimer Court's obiter comments regarding proportionality. Moreover, this aspect of the defence is afforded superordinate importance because the Court has held that in determining whether there is an air of reality to the claim of necessity, a trial judge is justified in moving directly to a consideration of whether the proportionality aspect of the defence can be satisfied. Thus, concerns about proportionality now operate front and centre in

(4.) Latimer, supra note 3 at 148 .

6) Perka, supra note 6 at 133. As noted above. supra note 22. the Latimer Court has formulated this notion of proportionality in more flexible terms.

65 See Stuart, supra note 57 at 514; and D. Galloway, "Necessity as a Justification: A Critique of Perka" (1986) 10 Dalhousie L.J. 158. 
necessity claims. Building on the Court's obiter statements regarding necessity and death in cases where homicide is involved, the defence should be kept from the jury.

This aspect of Latimer has been criticized as misguided. First, it is argued that the Court's obiter statement is supported by only American and British scholars, with the views of Canadian commentators being ignored. ${ }^{66}$ More importantly, Stuart argues, "The Court refers to Dudley and Stephens apparently unaware that its authority has been weakened by a recent ruling of the UK Court of Appeal that necessity would legalize an operation to separate conjoined twins." ${ }^{167}$ Whether the Supreme Court was unaware of the plight of the conjoined twins is debatable. However, it is difficult to say that $\operatorname{Re} A$ (Children) has truly "weakened" the authority of Dudley and Stephens. As discussed above, $\operatorname{Re} A$ (Children) is largely limited to its idiosyncratic context, focused on a set of facts that we hope may never need to be faced again. ${ }^{68}$ Key to the Court's decision was the notion of prior judicial authorization, a feature not available in any other context in which the defence might arise.

Moreover, the Court of Appeal in Re A (Children) was at pains to distinguish Dudley and Stephens. Each of the judgments, but especially the opinion of Brooke L.J., emphasized that some of the pragmatic issues that arose in Dudley and Stephens, such as whom would be selected as the victim and on what criteria, were not present in the case of the conjoined twins. Moreover, two of the judges considered the case of the conjoined twins as more akin to a case of quasi-self-defence, in the genre of the fallen mountaineer or the Zeebrugge disaster. Thus, the force of Dudley and Stephens is not weakened by $\operatorname{Re} A$ (Children). Even if it could be said that Dudley and Stephens has lost some of its authoritative value, the manner in which it was distinguished in $\operatorname{Re} A$ (Children) would have made no difference to the outcome in Latimer. Latimer had none of the confounding qualities that motivated the Court of Appeal in Re A (Children) to find a legal solution. At the centre of the conjoined twins case was the conflicting duties facing the doctors charged with the twins' care and the inevitability of death for both sisters without surgical intervention. In Latimer, there was no conflict of duty that required action be taken immediately. His daughter's death was not imminent. More fundamentally, no life was saved by the actions of Latimer, although at least one life was saved in $\operatorname{Re} A$ (Children).

\section{B. The Sanctity OF Life, InNOCENT Victims and INTENTIONAL Killing}

Underwriting the Latimer Court's position on necessity and death is an adherence to the sanctity-of-life principle that permeates Canadian criminal law. This notion of universality of rights was central to Wilson J.'s analysis in Perka, even though it was ultimately rejected by the Court of Appeal in $\operatorname{Re} A$ (Children). It is argued that the pre-

6h See Stuart, ibid. at 521 .

(1) Ibid. at 521-22. See also B. Sneiderman, "Latimer in the Supreme Court: Necessity, Compassionate Homicide, and Mandatory Sentencing" (2001) 64 Sask. L. Rev. 511 at 528-35.

6.X See R. Huxtable, "Separation of Conjoined Twins: Where Next for English Law?" [2002] Crim. L.R. 459. Huxtable suggests that the Court's holding is extremely narrow, even with respect to conjoined twins. But see J. Rogers, "Necessity, Private Defence and the Killing of Mary," supra note 62 at $516-17,521$. 
eminence of the sanctity of life in Canadian criminal law should foreclose the recognition of the defence of necessity in cases of homicide, broadly defined. At the very least, Latimer ought to stand for the proposition that an intentional killing, murder, can never be excused by virtue of necessity. In the balancing entailed by the third segment of the Latimer criteria, an intentional killing, because of its heightened level of moral blameworthiness, ought to receive greater weight in the comparison of harms calculus.

The most direct application of the sanctity-of-life principle in Canada is found in $R e$ Rodriguez and the Attorney-General of British Columbia. ${ }^{69}$ The Supreme Court considered the constitutionality of s. 241(b) of the Criminal Code, which prohibits aiding or abetting or assisting in someone else's suicide. Rodriguez suffered from a degenerative disease that would inevitably have taken her life. She wished to choose the time, place, and manner of her own death, but was prevented from doing so because of her disability. In order to end her life in the way she wished, Rodriguez needed the assistance of others. However, while committing or attempting to commit suicide is no longer unlawful in Canada, s. 241(b) of the Criminal Code makes it an offence to assist in someone else's suicide. Rodriguez claimed that, among other things, s. 241(b) infringed s. 7 of the Charter. ${ }^{70}$ This claim was rejected by a majority of the Court. In discussing whether Rodriguez's security of the person interests were engaged by her situation, Sopinka J., for the majority, made the following observations about the value of life in Canadian legal culture:

I find more merit in the argument that security of the person, by its nature. cannot encompass a right to take action that will end one's life as security of the person is intrinsically concerned with the wellbeing of the living person. This argument focuses on the generally held and deeply rooted belief in our society that human life is sacred or inviolable (which terms $I$ use in the non-religious sense described by Dworkin, Life's Dominion: An Argument About Abortion, Euthanasia, and Individual Freedom (1993), to mean that human life is seen to have a deep intrinsic value of its own). As members of a society based upon respect for the intrinsic value of human life and on the inherent dignity of every human being, can we incorporate within the Constitution, which embodies our most fundamental values, a right to terminate one's own life in any circumstances?...

Sanctity of life, as we will see, has been understood historically as excluding freedom of choice in the self-infliction of death and certainly in the involvement of others in carrying out that choice. ${ }^{71}$

A majority of the Court found that Rodriquez's security interests were violated by s. 241 (b) because s. 7 of the Charter includes the right to make choices concerning one's body, as well as control over one's physical and psychological well-being. ${ }^{72}$

(1993), 85 C.C.C. (3d) 15 (S.C.C.) [hereinafter Rodriguez].

Canadian Charter of Rights and Freedoms, Part I of the Constitution Act, 1982, being Schedule B to the Canada Act 1982 (U.K.), 1982, c. 11 [hereinafter Charter].

$"$ Rodriguez, supra note 69 at 61. See generally G. Williams, The Sanctity of Life and the Criminal Law (London: Faber \& Faber, 1957).

lbid. at 63. 
However, the majority found that Rodriguez's security interests were not infringed in a manner that violated the principles of fundamental justice. Justice Sopinka held that s. 24l(b) was designed to protect the vulnerable who might be persuaded to commit suicide in moments of weakness. ${ }^{73}$ After surveying the Anglo-Canadian legal landscape, the majority concluded that assisted suicide was worthy of criminalization for two reasons:

first, the active participation by one individual in the death of another is intrinsically morally and legally wrong, and secondly, there is no certainty that abuses can be prevented by anything less than a complete prohibition. ${ }^{74}$

However, it should be noted that the sanctity of life is not an absolute value in Canadian criminal law, given that abortions are legal in certain circumstances. ${ }^{75}$ Moreover, Canada, like many other countries, authorizes the withdrawal of lifesustaining medical treatment in some situations. ${ }^{76}$

The case for the vindication of the sanctity-of-life value is infinitely stronger in most criminal law situations beyond the highly specific context of the Rodriguez case. Rodriguez sought to have the principle compromised in order that she could die with dignity. There is obviously less scope for the attenuation of this value when one considers the right of one individual to kill another, who does not wish to die, and who does nothing to bring about his or her death. The sanctity-of-life principle thrives in those areas of the criminal law where one person harms another.

The highest value we respect is the life of another. ${ }^{77}$ Conduct that is considered the most serious in our criminal law is the intentional taking of that life. This value is exemplified in the societal revulsion and the severe consequences that follow a conviction for murder in Canada and elsewhere. This value is also reflected in the Canadian cases dealing with the constitutionality of various homicide provisions in the Criminal Code, particularly those considered to create "constructive murder" liability. In striking down s. 213(d) of the Criminal Code (the classic "constructive murder" provision) in $R$. v. Vaillancourt, ${ }^{78}$ the majority of the Court spoke in sweeping terms about murder in Canadian society:

$3 \quad$ lbid. at 69.

$74 \quad$ Ibid. at 73 [emphasis added].

75 Indeed, this point was made in the analysis of Brooke L.J. in $\operatorname{Re} A$ (Children), supra note 4 at 1051.

76 See Airedale N.H.S. Trust v. Bland, [1993] 2 W.L.R. 316 (H.L.), discussed in Rodriguez, supra note 69 and at great length in $\operatorname{Re} A$ (Children), supra note 4.

77 See A. Ashworth, Principles of Criminal Law, 3d ed. (Oxford: Oxford University Press, 1999) at 153. Sec Williams, supra note 47 at 603 , who says, "But many of us do believe in the sanctity of life - the 'natural right' of every man to his own life - and consequently believe that killing is absolutely wrong. This is an area, therefore, in which the defence of necessity, if allowed at all, is given very narrow scope." 
there are, though very few in number, certain crimes where, because of the special nature of the stigma attached to a conviction therefor or the available penalties. the principles of fundamental justice require a mens rea reflecting the particular nature of that crime... Murder is another such offence. The punishment for murder is the most severe in our society, and the stigma that attaches to a conviction for murder is similarly extreme. In addition, murder is distinguished from manslaughter only by the mental element with respect to the death. It is thus clear that there must be some special mental element with respect to the death before a culpable homicide can be treated as a murder. That special mental element gives rise to the moral blameworthiness which justifies the stigma and sentence attached to a murder conviction. ${ }^{79}$

This strong stance was reiterated in subsequent cases dealing with other murder provisions that provided for a conviction on something less than an intentional killing. ${ }^{80}$ Indeed, for the purposes of constitutional principles of fault, attempted murder was put on the same plane as murder, requiring a subjective intent to kill. As Lamer C.J.C. said in $R$. v. Logan, ${ }^{81}$

The stigma associated with a conviction for attempted murder is the same as it is for murder.... The attempted murderer is no less a killer than a murderer: he may be lucky - the ambulance arrived early, or some other fortuitous circumstance - but he still has the same killer instinct. ${ }^{82}$

Our commitment to the sanctity of life in Canadian criminal law reflects our revulsion for, to use the words of Sopinka J., the "active participation" of one person in another person's death, without that person's consent. The constitutionalization of fault cases emphasize the special place that an intentional killing (or an attempt to intentionally kill) has in our society. Still, the special features of murder that make it unique for fault purposes take us only so far in bolstering the sanctity of life concept in the context of necessity. A number of defences are recognized for murder - in particular, self-defence and provocation. However, for various reasons these defences contemplate situations where the victim has played a meaningful role in the scenario that resulted in his or her death. In the case of self-defence the victim will generally have acted in a way so as to give the accused a reasonable apprehension of harm, ${ }^{83}$ grievous bodily harm, or death. ${ }^{84}$ Exceptionally, a victim will not have acted in an aggressive manner, but self-defence may still apply if the accused's perception of the

Ibid. at 325-26.

See $R$. v. Martineau (1990), 79 C.R. (3d) 129 (S.C.C.). Lamer C.J.C. says, at 139: "Murder has long been recognized as the "worst' and most heinous of peace time crimes." (1990), 79 C.R. (3d) 169 (S.C.C.) [hereinafter Logan].

Ibid. at 178. See Ashworth, supra note 77, who challenges this approach, reflected in $R$. v. Gotts. [1992] 2 A.C. 412 (H.L.), which held that duress is not a defence to attempted murder. Ashworth writes, at 235, "The House of Lords seemed greatly impressed by the fact that it might be 'pure chance' that an attempted murderer did not succeed in murder. But there are many other parts of the criminal law where, logically or not. matters of luck and chance make considerable impact." See s. 34(1) of the Criminal Code, supra note 8.

See s. 34(2) of the Criminal Code, ibid. 
situation, though mistaken, was reasonable. ${ }^{85}$ In this sense, the application of the selfdefence provisions could, technically, result in the death of a truly "innocent" victim. This, however, is very different from the situation of necessity (and duress, discussed below), where the victim is truly "innocent" in the sense that his or her conduct does not in any way impinge or threaten to impinge on the bodily integrity of the accused person. ${ }^{86}$ Leaving aside the idiosyncratic cases of the conjoined twins, the fallen mountaineer or the Zeebrugge tragedy, where claims of quasi-self-defence might be tenable, true cases of necessity (and duress) involve victims who are blameless in the scenario that results in death. This distinction is crucial to balancing the harms required in necessity cases.

\section{The Analogue of Duress}

Because necessity and duress stem from the same root, we gain some insight into the necessity and death conundrum by seeing how Parliament and the courts have addressed duress and death. The present statutory and common law framework of duress now strongly supports the proposition that homicide is not excused by the defence of necessity. But as we shall see, reliance on the common law of duress to support the necessity and death thesis of this article is somewhat limited by the fact that the duress jurisprudence is tethered to the decision in Dudley and Stephens.

The Canadian codified version of duress, s. 17 of the Criminal Code, is clear in its exclusion of murder as an offence to which it might apply. Indeed, s. 17 contains numerous exclusions which commentators have identified as illogical or confusing. ${ }^{87}$ With one exception this criticism is unfounded. As one scrolls through the list of excluded offences, we see high treason or treason, murder, piracy, attempted murder, sexual assault, sexual assault with a weapon, threats to a third party or causing bodily harm, aggravated sexual assault, forcible abduction, hostage-taking, robbery, assault with a weapon or causing bodily harm, aggravated assault, unlawfully causing bodily harm, arson, or offences under sections 280 to 283 (abduction and detention of young persons). The list of offences is not illogical. Setting aside the antiquated offences of treason, there is a strong theme underlying this list - serious offences of intentional violence. Noticeable by their absence are other offences of violence that are either not

See $R$. v. Pétel (1994), 87 C.C.C. (3d) 97 (S.C.C.). Lamer C.J.C. said, at 104, "An honest but reasonable mistake as to the existence of an assault is therefore permitted.... The existence of an assault must not be made a kind of prerequisite for the exercise of self-defence to be assessed without regard to the perception of the accused. This would amount in a sense to trying the victim before the accused. In a case involving self-defence, it is the accused's state of mind that must be examined, and it is the accused (and not the victim) who must be given the benefit of a reasonable doubt. The question that the jury must ask itself is therefore not 'was the accused unlawfully assaulted?' but rather, 'did the accused reasonably believe, in the circumstances, that she was being unlawfully assaulted?'” Howe, supra note 35 , Lord Griffiths said, at 785 , that duress is denied as a defence to murder because "It is based on the special sanctity that the law attaches to human life and which denies to a man the right to take an innocent life even at the price of his own or another's life." 
as serious or the result of unintended consequences - manslaughter, ${ }^{88}$ simple assault, unlawfully causing bodily harm or death caused by criminal negligence. The section gives voice to the principle that it is not permissible to commit serious violence on another truly "innocent" person when confronted with immediate threats of death or bodily harm from another. The law does not permit one to privilege his or her physical integrity over that of an innocent third party. In these circumstances, the accused has no greater claim to physical integrity than the victim.

The questionable inclusion in the listed offences in $\mathrm{s} .17$ is robbery. This is the offence onto which commentators fasten when addressing the rationality of this section. Robbery is an odd inclusion, perhaps because robbery may be committed with no actual violence, merely the threat thereof. ${ }^{89}$ Robbery has confounded Parliament from time to time, especially in the context of homicide. Section 213(d), the constructive murder provision, included robbery as an offence that triggered its operation. However, robbery was left out of what is now s. 231 of the Code, the provision that elevates a seconddegree murder to first-degree murder when death is caused while the accused is committing one of the listed offences. ${ }^{90}$ The most that can be said is that, in the context of s. 17, the inclusion of robbery is anomalous.

Still, the message is clear that s. 17 does not apply to offences involving the intentional infliction of serious bodily harm. Given that we have no statutory defence of necessity, this Parliamentary expression is an important contextual factor in determining what is acceptable for the operation of the common law defence of necessity in Canada. Indeed, it may foreshadow what a codified defence of necessity might look like.

The analogy of duress for the necessity and death problem must take account of the impact of the Supreme Court's decision in R. v. Ruzic, ${ }^{91}$ in which the Court struck down certain preconditions to the operation of s. 17 of the Criminal Code, namely the requirements that the threats be immediate and that the person making the threat be present when the offence is committed. Building on its previous necessity and duress decisions, the Court held that the notion of "moral involuntariness" underwrites the Canadian law of necessity and duress and is a principle of fundamental justice for the purposes of s. 7 of the Charter. The Court stopped short of equating "moral involuntariness" with "moral blamelessness" because duress (and necessity) operate

It is recognized that some manslaughters involve the intentional killing of the victim, namely. intentional killings that are classified as manslaughter by virtue of the partial defence of provocation in s. 232 of the Criminal Code. See R. v. Cameron (1992), 71 C.C.C. (3d) 272 (Ont. C.A.).

*' See s. 343(a) of the Criminal Code. supra note 8.

*) The courts have struggled with this omission when dealing with robbery situations that reveal an aspect of forcible confinement, an offence that is included in s. 231. Compare $R$. v. Dollan and Newstead (1982), 65 C.C.C. (2d) 240 (Ont. C.A.) with R. v. Strong (1990), 2 C.R. (4th) 239 (Alta. C.A.). See also R. v. Kimberley and Clancey (2001). 157 C.C.C. (3d) 129 (Ont. C.A.); and R. v. Johnson (2002), 166 C.C.C. (3d) 44 (Ont. C.A.). 
outside the strict contours of fault, such that it cannot be said that someone who avails him or herself of the defence of duress is "blameless."

In coming to the conclusion that s. 17 of the Criminal Code infringed the Charter, the Court drew heavily on the more flexible common law version of the defence, along with considerations from the necessity defence. It seems inevitable that, given the broad nature of the Court's holding, the list of excluded offences in s. 17, perhaps even murder, will be attacked on the same basis in the future. However, there are aspects of the Court's judgment that suggest this might not be successful. Writing for the Court, LeBel J. put it as follows:

\begin{abstract}
The common law of duress, as restated by this Court in Hibbert recognizes that an accused in a situation of duress does not only enjoy rights, but also has obligations towards others and society. As a fellow human being, the accused remains subject to a basic duty to adjust his or her conduct to the importance and nature of the threat. The law includes a requirement of proportionality between the threat and the criminal act to be executed, measured on the objective-subjective standard of the reasonable person similarly situated. ${ }^{93}$
\end{abstract}

Thus, even though the Court's assertion of moral involuntariness as a principle of fundamental justice is breathtaking in its apparent scope, ${ }^{94}$ this passage suggests that the defence will be limited by proportionality.

The common law position on duress and death is complicated. First, the courts have wavered on the issue of whether the common law defence of duress could apply to an intentional killing. Secondly, the leading Canadian authority on this issue, $R$. v. Paquette, ${ }^{95}$ held that duress is available to someone who is a party, but not a principal, in the commission of a murder. As set out below, this decision was inspired by the British common law, which has since been reversed. Lastly, the debate in the English courts on this issue never really transcends the decision in Dudley and Stephens.

The current state of the law in England is that duress is not a defence to murder. ${ }^{96}$ The British Courts have struggled with this question. The source of the controversy can be traced back to Dudley and Stephens. In Lynch v. Director of Public Prosecutions for Northern Ireland ${ }^{97}$ the House of Lords sought to distinguish Dudley and Stephens on the basis that Lynch was not the principal actor in the murder of a policeman in Northern Ireland, but merely an aider and abettor. This distinction, the majority

Ibid. at 23

Ibid. at 25 [emphasis added]. It is odd that the Court conceived of the proportionality requirement for duress to be evaluated on a modified-objective basis, and not on a strictly objective basis, as the Latimer Court decided for necessity. As Stephen Coughlan has argued in "Duress, Necessity, Self-Defence and Provocation: Implications of Radical Change?" (2002) 7 Can. Crim. L.R. 147, perhaps this was an oversight.

See the comments of D. Stuart, “'Moral Involuntariness' Becomes Charter Standard for Defences" (2001) 41 C.R. (5th) 37.

(1976), 30 C.C.C. (2d) 417 (S.C.C.).

See J.C. Smith, Smith \& Hogan - Criminal Law, 9th ed. (London: Butterworths, 1999) at 233.

[1975] I All E.R. 913 (H.L.). 
concluded, justified the extension of the defence to the offence of murder. In the majority, Wilberforce L.J. held, "I find no convincing reason, on principle, why, if a defence of duress in the criminal law exists at all, it should be absolutely excluded in murder charges whatever the nature of the charge. ${ }^{" 98}$ The dissenting judges recognized that establishing a distinction between aiders and abettors and principals did not satisfactorily address the more fundamental implications of Dudley and Stephens. On the premise that Dudley and Stephens was correctly decided, Lord Simon of Glaisdale, for the dissenting judges, wrote that "it would be a travesty of justice and an invitation to anarchy to declare that an innocent life may be taken with impunity if the threat to one's own life is from a terrorist but not when from a natural disaster like ship or planewreck." 99

In Abbott v. The Queen, ${ }^{100}$ the Privy Council heard an appeal from the Court of Appeal of Trinidad and Tobago, involving the conviction of Abbott for the murder of a young woman. Abbott killed the woman, apparently under the directions of one Malik. Lord Salmon for the majority of the Board accepted that Malik was a dangerous individual, who had since been hanged for murder. ${ }^{101}$ The accused had performed various illegal tasks for Malik and was made to live in his compound. Malik eventually decided that a woman with whom he was associated should die. He directed Abbott to kill her, under threat of death to himself and his mother. Abbott led the woman to a grave that others had dug. The woman was stabbed and then buried alive. The Board held that, while it accepted the holding in Lynch that duress was available to a party, it was not prepared to extend that ruling to include the actual perpetrator of a killing. ${ }^{102}$ For the majority, Lord Salmon said, "It seems incredible to their Lordships that in any civilised society, acts such as the appellant's, whatever threats may have been made to him, could be regarded as excusable or within the law." 103

Ten years later, in $R$. v. Howe, ${ }^{104}$ the House of Lords reversed Lynch and once again aligned the defence of duress with Dudley and Stephens. Writing for the Court, Lord Hailsham said that he had participated in the majority in Abbott and did not directly quarrel with the holding in Lynch because Lynch had left the question open as to whether duress was available to a principal in the first degree. The Lord Chancellor considered the case to be a perfect opportunity to decide whether Lynch and Abbott should be permitted to stand together.

Ibid. at 927.

Ibid. at 936. Just above he states, "the man who pulls the trigger because his child will be killed otherwise is deserving of exactly the same consideration as the man who merely carries the gun because he is frightened."

[1976] 3 All E.R. 140 (P.C.) [hereinafter Abbott].

lbid. at 141 .

Ibid. at 144.

Ibid. at 146. In dissent, Lord Wilberforce and Lord Edmund-Davies, who were part of the majority in Lynch, held that there was no valid distinction to be made between a principal and a party to murder. They would have extended the defence to Abbott's situation. Ibid. at $148 \mathrm{ff}$.

Supra note 35. 
The Lords did recognize a distinction between duress and necessity in terms of the source of the threats operating on the accused person - with duress, the threats come from another individual, whereas with necessity the compulsion is by circumstance. ${ }^{105}$ Lord Hailsham held, "But I must say frankly that, if we were to allow this appeal, we should, I think, also have to say that $R$. v. Dudley and Stephens was bad law." ${ }^{106}$ The Court found the distinction, which merely recognized duress as a genus of necessity, was insufficient to justify the availability of one defence (duress) to a charge of murder and not the other (necessity). Lord Hailsham held, "I cannot see that there is any way in which a person of ordinary fortitude can be excused from the one type of pressure on his will rather than the other." 107 As with Lord Coleridge's words in Dudley and Stephens, Lord Hailsham's holding was immersed in notions of morality:

while there can never be a direct correspondence between law and morality, an attempt to divorce the two entirely is and has always proved to be doomed to failure, and, in the present case, the overriding objects of the criminal law must be to protect innocent lives and to set a standard of conduct which ordinary men and women are expected to observe if they are to avoid criminal responsibility. ${ }^{108}$

Each of the other Lords issued concurring decisions. In the opinion of Lord Griffiths, the limitation on the operation of duress ought to be extended to attempted murder because of "an even more evil intent to convict of attempted murder than in actual murder." 109 This position was formalized in $R$. v. Gotts, ${ }^{110}$ in which the House of Lords applied the holding to the offence of attempted murder. ${ }^{111}$

Thus, the British common law refuses to recognize duress as a defence to murder or attempted murder, notwithstanding the degree of participation of the accused. The manoeuvering of the British courts has left the Canadian law of duress in a bit of a quandary. In 1976, when Lynch was the controlling authority, the Supreme Court of Canada decided $R$. v. Paquette. ${ }^{12}$ Paquette was the driver for a robbery that resulted in the death of a store employee. By a combination of s. 21(2) and s. 213 of the Criminal Code, Paquette was convicted of murder. Paquette was unsuccessful in raising the defence of duress because, under s. 17 of the Code, murder is an excluded offence. The Court decided that, on the literal wording of s. 17, the statutory defence applies to "a person who commits an offence," and not "a person who is a party to an offence." 113 As Paquette was merely a party to the offence, s. 17 of the Code did not apply and he was entitled to rely on the common law defence, which, at the time,

$\begin{array}{ll}\text { IIIS } & \text { Ibid. at } 777 . \\ 111, & \text { lbid. } \\ 107 & \text { Ibid. } \\ 10 \% & \text { Ibid. at } 778 . \\ 10 \% & \text { Ibid. at } 790 . \\ 110 & {[1992] 1 \text { All E.R. } 832 \text { (H.L.). }}\end{array}$

III Ibid. at 840 . Lord Jauncey said, "I can therefore see no justification in logic, morality or law in affording to an attempted murderer the defence which is withheld from a murderer." This correspondence between murder and attempted murder is reflected in s. 17 of the Criminal Code. As set out above, it also has deeper roots, being reflected in constitutionally mandated principles of criminal liability: see Logan, supra note 81.

11: (1976), 30 C.C.C. (2d) 417 (S.C.C.) [hereinafter Paquette].

113 Ibid. at 421 . 
permitted parties to murder. On this point, ${ }^{114}$ and until the issue comes before the Court for consideration again, Paquette is still the law in Canada. The impetus for the Court's decision in Paquette may well be explained, not by the authenticity of the distinctions between parties and perpetrators, but by the tenuous basis of (constructive) liability for murder that existed at the time.

In conclusion, the defence of duress, both statutory and at common law, provides a powerful basis from which to assert that intentional homicide can never be excused on the basis of necessity. Even in the constitutional sphere, the Supreme Court in Ruzic has adverted to a proportionality component. In Latimer, the Court suggested that considerations of proportionality would prevent the application of necessity to homicide. If the two defences are to continue to live on the same juristic plane, the inclusion of death within the ambit of either seems unlikely.

\section{NECESSITY AND DEATH - THE FUTURE}

Despite the twists and turns of statute law and common law over the last century, the authority of Dudley and Stephens seems entrenched. Almost all indicators point to the preservation of the view that homicide will not be excused by the defence of necessity. In Latimer, the Supreme Court has all but laid to rest this issue with its persuasive obiter comments about homicide. This obiter is also supported by basic traditions of our criminal law that extend beyond the ambit of necessity and duress. It is consistent with the basic values of the sanctity of life and the right to protection of truly innocent victims in society. While the decision in $\operatorname{Re} A$ (Children) raises concerns about the fate of necessity and death in England, the case is so specialized that its effect is unlikely to extend beyond its narrow context.

The scope of the Latimer Court's pronouncement on necessity and death is clouded by the imprecision engendered by the term "homicide." As discussed above, there is a strong case for excluding intentional killings from the ambit of the defence. But what of other homicides that do not require a specific intent to kill, such as manslaughter and criminal negligence causing death? The defence of necessity has been pleaded in numerous motor vehicle cases in Canada, with some success. ${ }^{115}$ It is easy to imagine that the defence might be pleaded in a vehicular case involving death through criminal negligence or manslaughter. But it is unclear whether the defence of necessity would be available in the circumstances. Consider a case of criminal negligence involving a motor vehicle in which one victim is seriously injured and the other victim is killed.

In Hibbert, supra note 8, the Supreme Court overruled Paquette on the issue of the proper juristic basis of duress. Paquette held that duress negatived a common intention. In Hibbert, the Supreme Court held that moral involuntariness was at the core of defence, just as it was with necessity. See $R$. v. Hendricks (1988), 44 C.C.C. (3d) 52 (Sask. Q.B.) and R. v. Paul (1973), 12 C.C.C. (2d) 497 (N.S. Co. Ct.) where the defence did not succeed. The defence did succeed in $R$. v. Fry (1977), 36 C.C.C. (2d) 396 (Sask. Prov. Ct.), R. v. Kennedy (1972), 7 C.C.C. (2d) 42 (N.S. Co. Ct.) and $R$. v. Hunziker (2000), 3 M.V.R. (4th) 89 (Yukon Terr. Ct.). See also R. v. Martin, [1989] 1 All E.R. 652 (C.A.) (where the Court held that the defence ought to have been left in a driving case) and R. v. Conway, [1988] 3 All E.R. 1025 (C.A.) (where the Court quashed a conviction for reckless driving on the basis of necessity). 
The accused may plead necessity as a defence, relying on the exigencies involved in getting a seriously injured friend to the hospital. It is unclear whether the defence would apply to the offence involving the death of a victim. When intentionality is removed from the scenario, the harm caused (that is, death) is the same, but the seriousness of the offence itself is reduced. It is difficult to know if the Supreme Court will focus on the literal harm caused, as opposed to the relative seriousness of the situations that bring about that harm (negligent versus intentional conduct).

There is a strong case for Parliamentary action with the defence of necessity, particularly on the issue of whether a death can ever be justified. This is true of many aspects of substantive criminal law - the defences in particular. In recent years, there have been a few false starts with the distribution of a consultation paper on provocation, self-defence, and defence of property, ${ }^{116}$ as well as the recommendations of Ratushny J. in her important work on the Self-Defence Review. ${ }^{117}$ Nothing concrete has emerged from these events. Interestingly, Parliament has not been timid in the creation of new offences, as evidenced by the hasty enactment of myriad offencecreating provisions in the Anti-Terrorism Act. ${ }^{118}$

The issues raised in Latimer and $\operatorname{Re} A$ (Children) engage fundamental questions of value for our society. This has typically been the case with the necessity defence. Euthanasia, abortion, mercy-killing, and now surgical separation of non-consenting agents, fall to be determined on the judge-made law of necessity. While it is not always easy to determine ahead of time the sorts of claims that will be made under the rubric of the necessity defence, they are the sorts of issues that need to be addressed in a democratic forum. ${ }^{119}$ Indeed, Parliament might consider whether necessity (or duress) ought to be available as a mitigating factor, as opposed to an exculpatory defence, in cases of death. ${ }^{120}$ Legislative action would help to resolve these and other lingering questions left by the courts in Latimer and $\operatorname{Re} A$ (Children). As far as the British judiciary is concerned, legislative intervention would be a most welcome development. ${ }^{121}$ The same sentiment might prevail in Canada, if not from the bench, then from society at large.

116. Canada, Reforming Criminal Code Defences: Provocation, Self-Defence and Defence of Property (Ottawa: Department of Justice, 1998).

117 L. Ratushny, Self-Defence Review: Final Report (Ottawa: Department of Justice, 1997). See the discussion of this report in G.T. Trotter, "Justice, Politics and the Royal Prerogative of Mercy: Examining the Self-Defence Review" (2001) 26 Queen's L.J. 339.

IIx See Anti-Terrorism Act, S.C. 2001, c. 41, discussed in R.J. Daniels, P. Macklem \& K. Roach, eds., The Security of Freedom: Essays on Canada's Anti-Terrorism Bill (Toronto: University of Toronto Press, 2001).

119 This point is alluded to in J. Rogers, "Necessity, Private Defence and the Killing of Mary," supra note 62 at 522-24, under the heading "The Democracy Problem." See also Stuart Ryan's comment on the Rodriguez case, "Leaving Euthanasia for Parliament" (1994) 24 C.R. (4th) 366.

1:0 See Stephen, supra note 55 at 107-108 and Ashworth, supra note 77 at 285-86. See also W. Ferguson, "Necessity and Duress in Scots Law" [1986] Crim. L.R. 103 at 104, 109. This idea was discussed and rejected by Lord Hailsham in Howe, supra note 35 at 782 and Lord Griffiths at 785. See the proposals of Sneiderman, supra note 67 at 537-44.

1:1 See Hove, supra note 35 per Lord Bridge at 783; and Abbolt, supra note 100 per Salmon L.J. at 147. 